\title{
En Landsby i Midten af Sønderjylland.
}

(Bovlund).

Under forrige Krig havde vi en kvindelig Malkerøgter fra Ostkysten, der sagde, da hun første Gang kom herud: Her har I eller's æ Vær' aa æ fø'st Ha'end! Grunden til dette er jo, at vi ingen Hegn har, faa Skove, og store Flader. Vore Bakkeøer er mere udjævnede end Østkystlandskabet, saa vi kun faa Steder har bratte Fald. Bovlund Bakke skyder sig ud fra Toftlund Bakkeø, saa den har brede Kær og Engdrag baade mol Syd og Vest. Mod Sydøst og Syd er der $5 \mathrm{~km}$ over til Svejlunds og Østerterps Bakker i Aabenraa Amt. Midtvejs knejser en morsom Kuppel paa godt 1 Tønde Land, som Folk fra Nordsiden kalder "Hyholm«, medens de paa Syilsiden kalder den "Velleruphy «. Den bestaar af Sten og grovt Grus. Jeg har en privat Teori om, at dér har været et Hul i Bræell. Nu er dell mere end halvt fortaret til Vej- og Byggearbejder. Mod Vest har Bovlund Bakke et brat Fald mod Fladen, der $10 \mathrm{~km}$ mod vest begrænses af Nørre Løgum Bakker i Tønder Amt. Mellem Øster Terp Bakke og Nørre Løgum Bakke er der i Vestsydvest en Aabning, hvor igennem Fladen staar i Forbindelse med Bredeaafladen. Midt i demne Aabning ligger Cisterciensernes Klosterkirke $10 \mathrm{~km}$ borte. Dens Skib rager op over den lave $\mathrm{Br}_{\mathrm{r}}$, der har klynget sig om den. Man har altsaa den forhistoriske Tid og Middelalderen umiddelbart for Øje. - Den vide Horisont gør, at man her meget mere end mellem Hegn og Bakker ser Himlen.

Bakkeoverfladen har i fjerne Tider fortsat sig i en Dalbund over til Bakkerne i syd og Vest. For maaske 20-30,000 Aar siden, da den sidste Nedisning dannede Endemorrenerne mod Øst, har dens Smeltevandsfloder forst tabt Stenlagene ved Rødekro; Grus, Sand og Lerpartikler er fort læugere med, saa de har fyldt 
I)alene med en Flade, hos os bestaaende væsentligst af Grus, hvis Overflade falder 1 paa 1200 mod Vestsydvest.

At dette er mere end en graa Teori, kan man se, naar man, livor Fladen gaar ind mod Bakken, graver Brønd eller borer efter Vand.

Bakkerne er adskillige tusinde A:r ældre end Fladerne.

I Mellemistiderne (2, maaske 3 ) og efter Istiden har Planterne virket med. Selv i en Flade er der Højdeforskelle, om end smaa. I de noget højere Partier har Planterester og Dyreliv ciannet Muld, saa der blev Kærjord og Fælled. I de noget lavere Dele har der været Mordannelse, saa vore Enge har 10-60 cm Torvejord, et Lavmcselag, som indeholder omkring 2 pCt. Kalk og desuden andre Mineralstoffer (f. E. Jern), saa vore Engtorv giver megen Aske og Slagger. Askeskufferne fyldes 2-3 Gange om Dagen. Paa Fladen har der i gammel Tid staaet Skov. Maaske over det meste, men Kærjorden og Fælleden har jkke Betingelser for at kunne bevare Rester deraf. Humussyren i Engenes Tørvejord har jo derimod bevarende Evne. Til vor Gaard er 25 ha Eng, der er kultiveret siden 1913 - paa dette Areal har overalt været Skovrester, med Undtagelse af et ca. 1/4 lıa stort, lidt højere Parti, der fra gammel Tid hedder "Smirrepold" (Smedepold), hvor der er Myremalm, findes Slagger, og hvor der altsaa aabenbart er sket Jernudvinding i en Lysning i Skoven. I 1913 pløjede vi $1^{1 / 4}$ ha Eng. Mange Rester af blødt 'Træ (El, Elm, Ask, Birk, Hassel) kunde vi pløje igennem. Vi fincler mange velbevarede Hasselkapsler, ofte gnavede af Egern. Ilvor vi stødte paa Eg, maatte vi have Spade, Stænger og Kæde til $\mathrm{Hj}$ ælp for at faa ryddet, saa vi kunde komme frem. Det gav 7 store Læs sort Moseeg paa de $1^{1 / 4}$ ha. Det var mest Stub, altsaa efter fældet, Eg. De største kunde have Rødder ud til en I siameter paa $1 \frac{1}{2} \mathrm{~m}$. Mine Drenge og jeg blev enige om at kalde det "Tusindaarstræ«. V'ed senere at læse Pastor (senere Provst) Knud Aagaards, Agerskov, "Tørninglehns Beskrivelse« fra 1815, og ved at se gamle Korts Signaturer, har jeg set, at det ikke er sikkert. at det er saa gammelt. Aagaard skriver: "Før Ud- 
skiftningen (i 1773) var Kæret sønden for Bovlund bevokset med Buske af El, Birk og Hassel, hvor endnu levende Mænd har plukket Nødder, hvilket nu er forandret til Eng.« Nogle Steder er vi ved Engkultiveringer stødt paa hele, altsaa vindfældede Ege, hvoraf enkelte var over $50 \mathrm{~cm}$ tykke. De maa jo være mange hundrede Aar gamle, for der maa have været Overflod af Skov, da de faldt, saa ingen havde Interesse $i$ at bruge dem.

Det ældste skriftlige, man har om Bovlund, er fra 1266, da der skrives Borlund. Den har vel eksisteret, da Jydske Lov blev til. I en Arvesag fra et Egteskab fra 1863 gjorde en af de bedste Kendere af gammel slesvigsk Ret, Justitsraad Storm i Husum, i Firserne Amtsdommer i Toftlund, mig i 1911 opmærksom paa, at Jydske Lov regnede Huse for Løsøre, som kunde flyttes, da de hovedsagelig var af Træ. Saadanne antagelg lave og smalle Træhuse har hele Omegnen med dens mange "Skovnavne« haft Mulighed for at faa.

Før de dynastiske Interesser begyndte deres Rænker i Sønderjylland var Folkets Levevilkaar vel nogenlunde ens nord og syd for Kongeaaen. Men saa begyndte de danske Konger i Lighed med andre Steder at forsørge deres yngre Sønner ved at gøre dem til Hertuger over Dele af Sønderjylland. Disse Hertuger stræbte efter at gøre sig saa selvstændige som muligt, hvortil de søgte tysk Støtte, saa de med enkelte hæderlige Undtagelser virkede fortyskende, og de søgte at faa meget ud af deres Fyrstendømme, hvilket ogsaa materielt kom til at gaa ud over Folket.

Den ugifte Hertug Hans den ældre paa Haderslevhus (Hansborg) havde været en dygtig og ret loyal Regent. Da han døde i 1580, arvede hans Brodersøn, Kong Frederik II Haderslev Amt, som derefter vedblev at være kongerigsk. Frederik II. blev altsaa sønderjydsk Hertug og sin egen Konge. Selv efter at Enevælden var indført i Danmark, vedblev den kongerigske Del af Sønderjylland af de danske Konger at blive betragtet som en mere privat Ejendom. Reformer, som man onskede 
indført i Danmark, prøvedes først i Sønderjylland. F. Eks. fik vi Lovene om Udskiftningen 10 Aar, før de kom i Kongeriget.

Frederik II. udkøbte Herremændene i Haderslev Amt med Undtagelse af ham paa Gram, og lod Bønderne faa Gaardene i et frit og godt Arvefæste, de kunde sælges og pantsættes, saa det kom meget nær et Selveje med en Jordafgift. Bønderne i Haderslev Amt blev derfor i deres Karakter paavirket paa samme Maade, som Selvejet virker. De blev selvstæendige og holdt paa deres Ret, naar andre kom dem for nær. Lige Syd for, i Aabenraa Amt, havde Forholdene været anderledes. Det var den Gottorpske Del. I 1713 blev den Gottorpske Del af Sønderjylland inddraget under Kronen, blev kongerigsk - men Paavirkningen blev ved at holde sig - ja til den Dag i Dag. Folkepræg ændres langsomt. Min Moster, der var født 1831, blev ved med til sin Død 1899 at sige "Ovre i æ Hertugdøm'« om Egriene Syd for Bovlund. De store Bønder i den Gottorpske Del var tidligt blevet tyskpaavirkede, selv om de talte Dansk. Hertug Christian August af Augustenborg, der var snild og dygtig, kom til dem paa Jagt, og de blev budt til Taffels paa Augustenborg - noget saa attraaværdigt, saa Fru Wagner for 1848 som lille Pige fra Sundeved var kørende med sin Fader for at se paa Forestillingen. Der var trukket en Snor $i$ Salen, saa Publikum kunde passere forbi og se de begunstigede spise. Haderslev Amt havde af historiske og geografiske Grun-. de meget større Forbindelse og Paavirkning nordfra. En tidlig, stille og klar Foraarsdag i 1936 kørte jeg gennem Nordslesvig fra Nord til Syd. Mange var ved at sprede Kunstgødning. I Haderslev Amt rog det hvidt af Superfosfat, som danske Konsulenter anbefaler. Saa snart jeg kom ind i det Gottorpske, rag det sort af Thomasslagge, som vi brugte $i$ den tyske Tid. Pudsigt nok den Dag uden Undtagelse.

Bønderne var allerede $i$ det attende Aarhundrede forholdsvis velstillet og oplyst i Sønderjylland. Dyssel skriver i 1774: "Overalt i det Slesvigske oplæres Bønderbørn meget ypperligt 
i Skrivning og Regnekunst indtil Algebra. Det er en herlig Folge af den lyksalige Frihed, som den slesvigske Bonde nyder«. Man kan næsten komme til at tro, at Dyssel ser for lyst, men den nøgterne og paaliclelige Knud Aagaard, der i 1806 var kommet fra Thy til Agerskov, skriver i 1815: "Skønt der er Krise, er Skoleundervisningen drevet med større Flid end nogensteds i Danmark. Der er kun faa faste Skoleholdere. En By cller visse Beboere lejer for V'interen en Karl for 8-16 Rigshankdalere til at undervise deres Børn«. Et Hus til en saadan V'interskole var der i Bovlund, hvis Syld vi har taget op lige Ost for Hulvejen, der gaar fra Andreas Jacobsens Gaard til Bovlund $\mathrm{By}$, og et lignende var der i V'ellerup. I 1832 byggede Vellerup og Bovlund en større Fællesskole paa Bovlund Bjerg, hvor der før kun havde været en Kro med Gaardbrug og et Husmandssted. Der blev lagt Jord til, ydet Naturalier og lavet Lærerbolig og en fire Fags Skolestue i Husets Bredde, som blev henyttet af 72 Børn indtil 1912.

Aagaard beskriver Levemaaden og tilføjer: "Det Stykke Flæsk, som en Husmoder i Thy uddeler til 3 Personer, anses her ikkun tilstrækkelig til en«. "Det er ikke sjældent at se Bønderpiger iførte Silke- eller Sirtseskjoler med Straahatte paa Hovedet«. "Finder man større Tarvelighed og Nøjsomhed hos Nørrejyder end hos Sønderjyder, saa er det unægteligt, at man med større Velbehag træder ind $i$ disses end i hines Huse. Udslæt og Hudsygdomme findes meget sjældent her, endog hos de fattigste«. Sønderjyderne saa ned paa Nørrejyderne - meget længere end der var endog Spor af Grund til det; saaledes blev der €ndnu i min Barndom sagt, at man i visse Egne af Nørrejylland havde en "Kløpæl" midt i Stuen.

Aagaard lærte ogsaa Sønderjydernes stejle og uimponerede Sind at kende. Da han vilde indføre en $n y$, rationalistisk Gudstjenesteordning og "Den evangelisk kristelige Salmebog", som fortrængte Kingos og Brorsons Salmer, protesterede de. Af 36 protesterende var 21 fra Bovlund. Da det ikke hjalp, ind- 
sendte 104 "af de storste Familier"i Agerskov Sogn en Klage til Kongen. Den blev afvist.

Grunden til Modstanden var ikke alene almindelig Konservatisme, men der laa ogsaa religiøse Grunde bag. I Bedsted havde Hans Adolf Brorsons Broder været Prast, og andre Pietister og Hernhutterne havde virket med til at holde den gamle Gudstro levende.

I gamle Dage regnede man med den slesvigske Tønde Land $={ }^{2 / 3}$ ha, ja den slesvigske Tande holdt sig længe efter, at Metersystemet først i Halvfemserne var indført i Preussen. Endnu ved 1900 blev der Mand og Mand imellem regnet med Tønder I.and a ${ }^{2 / 3}$ ha.

Aagaard opgiver i 1815, at Bovlund har $1819 \mathrm{Td}$, hvoraf 1013 Td. er Eng, 419 Td. Ager og 397 'Td. Hede. Det viser, hvilken arealmæssig Betydning den lave Jord (Fladen) har. Albrecht Thaer gav jo omkring 1800 Udtryk for den almindelige Opfattelse ved at skrive, at Engen er Agerens Moder. Ogsaa Bønderne var af den Opfatteise. "Paa Engenes Forbedring spares ingen Flid«. "Naar Høet et Par Dage har staaet i smaa Stakke, bæres disse sammen i større efter Spredning«. "Man regner dem for gode Byer, der som Bovlund og Roost har 40 Læs Hø til 1 Otting, medens magre Byer som Agerskov og Rangstrup kun har 12-20 Læs Hø pr. Otting «. Der gik 4 Ottinger praa en Helgaard, og Aagaard mener, at 1 Otting omtrent svarer til $2 \mathrm{Td}$. Hartkorn. Bovlund havde 50 Ottinger, fordelt paa 16 Gaarde, 8 Huse og 12 "Inderster". For Udskiftningen ejede Kaadneren gærne Huset og havde Ret til Græsning af et Par Køer paa Fællesjorden. Efter Udskiftningen havde Indersterne ofte Bygninger og Jord lejet af en Gaardmand og betaler denne for Hestearbejdet. Man regnede 4 Kaadnerhuse til 1 Otting.

De 16 Hel-, Trekvart- og Halvgaarde og nogle af Husene og Kaadnerhusene laa tæt pakket, Side om Side, i en Bue omkring Bakkefoden, saa Vejen havde Bakken til den ene Side, 
og Bygningerne paa den anden. Da én forleden spurgte mig, hvorfor man i sin Tid havde lagt Bovlund, saa der var Pløre i Efteraaret, og man føg til om Vinteren, var jeg ikke i Tvivl om Svaret: For at kunne naa Vandet med en Kampestensbrønd og en Brondvippe.

I 1773 brændte Byen. Der siges, at man sendte Bud efter en Præst, der kunde mere end sit Fadervor. Han red tre Gange rundt om Byen, og saa fik man Ilden standset ved Korsvejen, der gaar paa tværs af Bygaden. Tvivlere, der vel ogsaa har levet, da Sagnet blev til, siger, at det ogsaa hjalp til, at der var Modblæst.

Efter Afskrifter af Nørre Rangstrup Herreds Tingbog, som Dr. Troels Fink har foretaget, og jeg har faaet Lov til at læse, har man allerede i 1730 i Bovlund foretaget Magelæg af Englodder, som blev taget ud af Fællesskabet. Foruden Tingsvidnerne var der 18 Navne under Forretningen. Det var atter for Tinget i 1732, 1740 og 1744, hvor Protester blev behandlet. Tilsidst har alle 25 Lodsejere underskrevet et Forlig. Branden i 1773 gav Stødet til en fuldstændig Udskiftning og delvis Udflytning. Bymarken blev opmaalt af Landmaaler Hans Clemendsen i Gestrup, der sammen med 2 Sandemænd fra Vellerup og 1 fra Branderup foretog en Bonitering, saa Udskiftningen kunde foretages efter Areal og Godhed. Man er paa Forhaand tilbøjelig til at antage, at "Smaafolkene" (Boelsmænd. Kaadnere, Inderster og Forbedelser) vilde trække det korte Straa ved Udskiftningen. Det er overraskende og glædeligt at se, hvor godt de er i Stand til at holde paa og faa deres Ret :Forbedelserne i Boulund for Retten fremkom og reserveret dem deris Rett i Byen som de haver haft af ganmel Tiid, efter en gammel Tingsvindes Copi D. dato 19. Jan. 1591, som Boulund Naboer haver schreeven deris Navne under 1719 «, hvori deres Græsningsret fastslaaes.

4 Forbedelser, som klagede, fik for deres Græsningsret 3 Ottinger, altsaa hver $3 / 4$ Otting, saa de kunde med god Grund skrive under paa, at de nu var tilfredsstillet. Peder Hansen 
F'løj skrev under "med førte Haand — de andre kunde selv skrive deres Navne.

Den egentlige Udskiftning begyndte 1773, Jorderne blev opmaalt og boniteret 1776 og delt 1785 .

Gaarden, som nu er døbt Thorsmark, de 2 Gaarde paa Mølbjerg (1784 var der 3 Mølbjerggaarde) og Kaadnersteder i Baalsted og Nymark og et Kaadnersted paa Bovlundbjerg blev udflyttet, saa der blev mere Plads mellem Gaardene i Byen. Allerede længe før Branden var de Bygninger, som hovedsagelig var af Træ, forsvundet, efter at Skovene var blevet forhuggede. I Stedet blev Kamp- og Mursten benyttet. Man havde ikke brandforsikret. Naar en Bygning var brændt, eller man af anden Grund vilde bygge, lavede man sig af Kampesten en Ovn, der kunde rumme omkring 5000 Mursten og Naboerne hjalp til med at faa bygget. Den gensidige Hjælpsomhed erstattede Forsikringerne. I mine Drengeaar i Firserne var der mange Rester tilbage af de Bygninger, der blev opført efter Branden - ja endnu er der Spor tilbage. De var smalle og lave. En jævnhøj Mand maatte bøje sig, for at komme under Dørkarmen, og man kunde støde Panden mod Bjælkerne. Der var grønlig, blyindfattede Ruder i Vinduerne, som ikke kunde lukkes op. I Stedet for egentlige Soveværelser var der "Indlaatsseng" (Alkover) i æ Døns (Dagligstuen). Jeg har ofte sovet i Alkover, saa jeg ved, at Folkemaalets Betegnelse var træffende - og det var værre den Gang, da Vinduerne ikke kunde aabnes. En Overgangsform mellem Alkove og alm. Soveværelse fik nogle ved at lave et lille Sovekammer midt inde i Huset, saa det kun havde Vindue ud til Forstuen, som endog kunde vende mod Nord. Jeg kender en Gaard, hvor man endnu benytter et saadant Sovekammer, dog med Forstuen mod Syd. Alkoven og' de tilsømmede Vinduer var medvirkende til den store Udbredelse, Tuberkulosen havde. I Stedet for Komfur havde man aabent Ildsted, Arne, med en et Fag vid Skorsten over. Mod Ovnen mundede Aabningen af Bageovnen, indtil den paa Grund af Brandfaren blev tvunget 
udenfor til et særskilt liggende Ovnhus. Til at bære Gryderne havde man en Jerntrefod, eller de kunde hænges i en Kjeldskle, hvorfra Gaaden: "Klink op, klink ned? min Kjeldskle«. Indtil Arnen mundede ogsaa Aabningen af Dagligstuens Bilæggerovn, som altsaa blev fyret fra Arnen. Den virkede altsaa ikke til Luftfornyelse i Dagligstuen. Der blev sikkert ikke flottet med Varmen i den Tid. Vi Drenge kiggede ofte om Vinteraftenerne ind ad de blyindfattede Ruder til en Kaadner, der var fodt omkring 1800 Tallet, om han som sædvanlig var kravlet op paa Bilæggeren, for at ingen Varme skulde gaa til Spilde.

Gaardens Dagligstue var Vinteraftener fyldt af Familien og Tyendet. Kvinderne kartede Uld eller spandt Uld eller Hør. Karlene lavede Tækkereb af Ruglanghalm. "Det paaligger hver Tjenestekarl om Vinteraftener at sno 100 Tækkereb hver paa 5 Favne«. I de 8 Huse og 12 Kaadnersteden har man foruden lignende Selvforsyningsarbejder haft travlt med at kniple for at tjene rede Penge ind. Der gik en Grænse for Hjemmeindustri saaledes, at man i Agerskov Vestersogn kniplede, i Ostersognet strikkede man Strømper, Trøjer og Huer til Salg, foruden at man i Rangstrup brændte Tørvekul, der blev solgt til Smedekul. For at spare paa Lys og Varme gik man sammen med Knipleskrin og Lyskugle, en vandfyldt Glaskugle, der ved at virke som Brændglas kunde samle Lyset paa Kniplingen.

Naar man ser paa Aagaards foranforte Onitale af Indersterne, er jeg tilbøjelig til at tro, at de har faaet forholdsvis mindst Udbytte af Udskiftningen. Fællesskabet havde mange Ulemper og var moden til at forsvinde. Kun naar enhver havde fri Raadighed over sin Særmark, var der Mulighed for Fremskridt ved, at den individuelle Dygtighed kunde udfolde sig. Men Landsbyfællesskabet havde ogsaa i nogen Grad været en Stotte for de svage. Ved selve Udskiftningen var der jo nogen Nulighed for, at den klogeste, dygtigste og stærkeste trak det længste Straa. Jeg har dog ikke tilstrækkelig Viden om Indersternes Levevilkaar før og efter Udskiftningen til at begrunde mere end en Formodning. Derimod ved jeg, at Inder- 
sterne og Kaadneme havde en lav Levefod i Forhold til Bønderne i første Halvilel af det nittende Aarhundrede. Den foran omtalte Kaadner, der var født omkring 1800 , boede til at begv nde med i en Hytte med Vagge af Græstørv. Ogsaa om en anden vides det, at han boede i et "Sajthus«. Naar Kaadneren havde faaet en Bøtte Smør samlet, startede han, før Fanden fik Sko paa, med Mellemmad, Træsko og Smørbøtte paa Trillebøren de $3^{1 / 2}$ Mil mod Aabenraa. Der blev ikke givet en Skilling ud paa hele Turen, og Sliddet paa Fodtøjet var kun, at Træskoene blev brugt i Aabenraa. Man siger, at han en Gang ned ad Skedebjerg, hvor Vejen den Gang faldt mere brat, kom i en saadan Fart, at Smørhøtten hoppede af og trillede foran. Da han var bleven Enkemand, tilberedte han selv Maden paa den Maade, at hau kogte Grød til en hel Uge, og der gik den "Krønike (maasko er det et Vandresagn), at naar Grøden sidst paa Ugen var ved at blive lodden, saa den ikke rigtig vilde skride ned, saa skankede han sig en Snaps (af den til 27 Penning Flasken) og sagde til sig selv: Den faar Du, naar Tallerkeıen er tom! Men naar Maalet var naaet, hællte han Snapsen i Flasken og sagde: Ha! der suød Du Dig godt! Selv om han vel nok var Mesteren i Slid og Sparsommelighed, saa var alle flittige og havde Respekt for rede Penge. Da Tiderne sidst i 1820 erne begyndte saa smaat at bedres, kunde man faa bedre Huse og faa Marken forbedret.

I Agerskov begyndte enkelte at bruge M e rge l i 1795. I Bovlund, hvor man takket være den store Høavl ikke trængte saa haardt til storre Hostudbytte, holdt man igen med at belytte det nye Middel, son jo skulde give en rig Fader og en fattig Son. Fra flere Sider har jeg den mundtlige Overlevering, at man for Merglingen ikke kunde dyrke Byg paa Bovlund Agermark, der jo ellers ved Hjalp af det meget $\mathrm{Hø}$ kunde godes stærkt. Derfor havde hver Gaard ell Bygager ved Branderup Mølle, hvor der er en rød, kalk- os jernholdig Slemjord. Saaledes fik man altsaa Byg til Gryn og Malt. Med Hensyn til Gryn var "Tarre" (Boghvele) IIovedsagen. Selv om man saale- 
des kunde hjælpe sig uden Mergel til Agermarken, saa laa det nær ved Hjælp af den at angribe Heden, de lynggroede, lidt højere Partier af Fladen. Der var Engmergel visse Steder, men den var vanskelig at komme til for Vand, og den virkede cgsaa for hurtigt og kraftigt, saa Jorden blev for los og »olm«. I Bakken var der ogsaa Mergel, rigtignok kun mager, saa der skulde anvendes meget af den, og den laa dybt, saa der var megen Afrømning. Til Gengæld virkede den heldigt og længe -- dens Lerindhold virkede ogsaa gavnligt i den stærkt humusholdige Hede. I Bakkejorden har vi nu dels mindre Mergelgrave, hvorfra senere den omliggende Agermark er bleven merglet, dels store Grave, hvorfra ogsaa Heden er blevet merglet. I Bakkens bratte Fald mod Vest er der en stor Mergelgrav, som nu kaldes æ Dal. Derfra har man kunnet køre Mergelen ud med Hestekøretøj; Vandet kunde selv løbe bort. Fra den har Baalstederne, der ikke havde Lermergel i deres egen Jord, hentet Mergel til deres Hede.

Det var et stort Arbejde at mergle og kultivere Heden, men til Gengæld fik man god Jord, fortrinlig til Græsning og Hoslæt, og brugelig til Kornavl, om end Straaet blev mindre stivstraaet, lettere gik i Leje, end paa Bakkejorden. Efter Hedens Opdyrkning gik man i Gang med at mergle Bakkejorden. Min Moster, der var født 1831, har fortalt, at hun som lille Pige hjalp til med at køre Mergel ud, skønt hun var Datter af en velstillet Gaardmand. Hun har naturligvis kørt Mellemvognen, saa de maa have haft 3 spand i Gang. Man har altsaa ikke forst i Fyrrerne været færdig med forste Gangs Mergling af Agermarken.

Naar jeg nu forlader den Del, hvortil Knud Aagaard hovedsagelig har været Kilden, saa er der Grund til at nævne, at han var en af de første, der varmt gjorde opmærksom paa det meningsløse $i$, at Tysk $i$ et dansk Land af Myndighederne benyttedes over for en Befolkning med dansk Modersmaal. Han kom i saa Henseende 16 Aar før P. D. Chr. Paulsens berømte Skrift om Danskheden i Sønderjylland, men Aagaards Indlæg 
var mere lejlighedsvis og naturligvis ikke saa vægtigt og virkningsfuldt som Paulsens.

Jørgen Fausbøl paa Branderupmølle, hvis meste Jord ligger i Bovlund, har samlet og i 1910 udgivet "Minder fra Agerskov Sogn«. Jeg husker 60 Aar tilbage, og de gamle Folk, jeg har lyttet til, fortalte om "Bonepart« (Napoleon), altsaa 130 Aar tilbage.

Den forholdsvise Velstand hos Bønderne i vor Egn, som Aagaard skildrede i 1815, holdt sig ikke, selv om det ikke blev saa strængt, som Nord og Øst for Kongeaaen. Omslaget i Tiderne var jo allerede forlængst begyndt i 1815. Krigen og StatsLankerotten i 1813 havde virket. Papirspengene blev værdiløse. Min Moster fortalte, hvorledes Bedstefader gemte 8000 Daler i Papir, som en Mand havde givet ham og sagt "Kvit". De var og blev værdiløse. Det blev i Familien anset for at være et Slags Kæltringeri, man havde været ude for. De virkelige Priser paa Landbrugsprodukter sank og holdt sig meget lave i lang Tid - først ved 1828-30 begyndte en langsom Stigning. Der maatte slides og spinkes og spares. Man maatte tage det, som senere Kromanden i "Nykro". Konen raabte ud til ham: Quitzau! Skal 'et vær' Vælling eller Grød? Helst V'ælling, de tejer it saa manne Gryn! Ellers var det jo særlig de rede Penge, det var smaat med. Naar det var saa strengt og smaat, saa maatte man have noget til at sætte Kulør paa Tilværelsen. Man brændte Brændevin i hver Gaard. Vel var det forbudt; forst at brænde til Salg, senere al Hjemmebrænding. De dyre Kobberremedier dertil blev konfiskeret, naar det blev opdaget. Men det var, som om den forbudne Frugt kom til at smage endnu bedre. Foruden for $i$ al Almindelighed at lette Sindet, var Brændevinen næsten ogsaa nødvendig til den megen Saltmad, som den stod paa i Aarets 11 Maaneder. Naar en Gaard havde brændt Brændevin, kom Naboerne for at smage - og hele Byen fik en "Letter", en "Gibenakker" -- det kære Barn havde mange Navne, som tildels indeholdt en Gradsbetegnelse. Var den høj, havde man: "traa't Pe'r a æ Lovt«. Den daglige 
Sinaps til Maden hørte sig til, Kaffepunsch kom frem og blev almindelig, eller man drak en Drik fremstillet af Dagligøl, Sirup og Brændevin, undertiden blev der trakteret med Mjod - Resultatet var, at mange fik mere Spiritus, end godt var, ja adskillige blev drikfældige. Jeg ved endog Koner, rler var det.

Nogle maa selv under den fattige Tid have haft en Reserve af blanke Dalere paa Kistebunden. Vor Nabogaard el i mange Henseender lærerig. Den var sikkert ell Gang i det attende Aarhundrede ${ }^{1 / 2}$ Fæstegaard, altsaa 2 Ottinger. Først ejede Rasmus Jepsen den, saa Hans Rasmussen (forst i 1771 blev det befalet, at enhver skulde føre fast Stamnavn). I 1785 (tysk Dokument) faar Hans Petersen den, hall kan jo have giftet sig ind (Enker med Gaard var efterspurgte). Et gulnet Skriftstykke paa tysk fra 1797, der svarer til de nuværende Artikelbogsuddrag, viser, at Hans Petersen ogsaa har 1 Enottinggaard paa

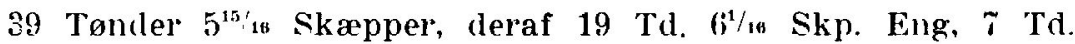
$2^{4 / 16}$ Skp. Azer og 12 Td. $5^{6 / 1}$ skp. Hede. Senere blev ogsaa Heden til Eng eller Græsning. Demme ene Otting har jkke haft særlige Bygninger, men hele Gaarden blev nu paa 3 ottinger, med ialt ca. 79,5 ha.

Mads Christensen faar den i 1799 (trsk Dokument). I Fæstepenge (Indløsning) betales der hver Gang 8 Rigshankdaler rede Sølv af hver Otting for Ejerskiftet.

Mathias Bertelsen Møller faar dell 1810 (tysks Papirer). I 1834 gifter hans Enke sig med Chr. Simonsen fra Rurup, og den 16-aarige Ansine Møller bliver ndskiftet (nu paa Dansk) med 2320 Rigsbankdaler relle Solv. Selv on "Tiden« nu var $i$ langsom Bedring, kunde denne Sum ikke vare holdt over siden Statshankerotten. Nu bedres Tiderne javnt I 1841 kober Chr. Simonsen et Ejendomskaadnersted paa godt 9 ha ind til. 1845 bytter Simonsen Gaard med Marten Refslund, der var født paa vor Gaard i Bovlund, men den ældste Søn Hans Refslund fik naturligvis Gaarden, og saa matte den yngre enten son almindeligt blive gaaende ugift cg arbejde paa Stavnen. finde en Enke med en Gaard, eller en velhavencle Kixreste, saa man kunde 
købe en Gaard. Marten Refslund blev forlovet med Ellen Johnsen fra den nordøstligste Gaard (paa 90 ha). Ellen Johnsens Moder (forresten min Oldemoder) Maren Hanses var dygtig, men noget "storhjarte«. Hun fantaserede om, at de skulde flytte Gaarden op paa Bakken: "Saa skal mit og Hanses Navn staa i Guldtøgger (Bogstaver) paa Kvisten«. Men Hans vilde hellere lægge paa Kistebunden. Marten Refslund og Ellen købte Skibelundgaard i Branderup, og der blev deres Børn fodt, men han vilde hellere igen til Bovlund, for: "A vist it for $\infty$ liom til Branderup, te æ Mølstrøm (der gør Skel mellem Bovlund og Branderup Enge) gik for nørle«. Man holdt af at udtryke sig forblommet. Ved Byttet med Chr. Simonsen kom der i Salgsdokumentet til at staa, at Marten Refslund skulde give 3200 Rigsbankdaler i rede Sølv. Nu havde man Dalerne. Vel svingede Priserne paa Landbrugsprodukterne, men Hovedlinjen var en støt Stigning, og Udgifterue steg ikke tilsvarende. Det blev smat for Tyendet og Arbejdsfolk. De Bønder, der sad paa Gaardene, huskede alt for godt, hvor smaat det kunde blive, saa de sled og spinkede og sparede endnu, selv om det nu ikke var en Nodvendighed mere. Den ryddede og første Gang merglede Jord havde givet store Afgrøder. Det var dygtige Bønder, og de havde Sans for mere end at samle Penge. 2 af Bønderne sendte deres Sønner til den lige oprettede Rødding; Hojskoles 2 Vintres Kursus. Om det Slagtleds Tænkemaade tror jeg at kunne have nogen Mening fra gamle Folk, der som unge havde faaet deres Præg af den.

Det almindelige var jo, at den aldste Son skulde have Gaarden kvit og frit, og saa fik de andre Børn rede Penge til Deling, saaledes at Sanner fik en Broderpart, der var dobbelt saa stor som en Søsterpart. Denne Arvedeling var ogsaa en Spore for Forældrene til at samle rede Penge. Til Gengæld for den mindre Sosterpart fik Dotrene et forsvarligt Udstyr. Hver fik blandt andet en kunstfrerdigt beslaaet og malet "Helkiste«, proppet fuld af Sengetøj og broderet Linned. Det tog lang Tid at dyrke Hørren og lave det tilrette, saa man begyndte straks. 
Der var Brudelinned og meget andet. En Dag i Firserne havde nin Søster været ved at rydde op i Mosters Kiste, og saa kom hun glædestraalende ned med et Linnedkunstværk over Armene: "Nej, Moster, hvad er det dog her, jeg finder!" Moster hlev lidt forlegen og vilde ikke rykke ud med Sproget, men Søster blev ved at trænge paa, og saa kom det til sidst: „Det er min Ligsærk «. Søster gav et Skrig og smed Linnedet, og hun blev ved at græde og klage, indtil Moster gav Lov til at brænde L.igsærken. Jeg husker det, som om det var to ret forskellige Livsindstillinger, der mødtes. De kunde ikke gaa hen at købe alting færdig. Moderen og den unge Pige har siddet og syet ikke alene Brudelinnedet, men ogsaa Ligsærken. Da førte der altid en bred Dør gennem Gavlen ind i æ Pissel (Storstuen) - den var lavet til Ligkisten, der ikke kunde komme anden Vej. De gamle har sikkert haft en Livsindstilling i Lighed med Sagaog Vikingetiden, da en tynd Planke bar over det dybe Hav. Man var ikke saa ræd for Døden, som senere. Det var en mere dramatisk Indstilling. I samme Retning virkede, at man ikke benyttede Sygehuse og Sindssygehospitaler. Vi maa vare glale ved, at vi har dem, men at de almindelig Syge og de Sindssyge blev i Hjemmene, maa have paavirket Livsindstillingen, gjort den dybere. Moster sagde tit: at dø er ikke det værste, cler kan ske!

Der var ogsaa nogen Skæbnetro, maaske en Rest helt fra Hedenskabet. De gamle Koner sagde i Firserne: "Det skulde nu saa være", og saa rystede de alvidende paa Hovederne. De troede fast og sikkert paa Varsler og Spogeri. Mørket var ikke alene mere knugende, fordi de kunstige Lyskilder var saa priInitive (i $1863 \mathrm{kom}$ den første Petroleumslampe til Byen), men desuden dækkede det over Væsener, der kunde være fjendtlige og i hvert Fald var uden for den tørre Fornuft. Mændene sled altsaa i det, men Kvindernes Arbejdsindsats var meget storre og mere trælsom, og det holdt sig længere end Mændenes overIrevne Slid.: Helt til Fabrikkerne, Mejerier, Bagerier, Slagterier og Ølbryggerier aflastede dem i 1890erne. Naar Mændene 
i den lange Sommerdag fik sig en Middagssøvn, saa vadskede Pigerne op og malkede til Middag. Naar Karlene eiter Aftensmaden var fri, skulde Pigerne vadske op, derefter om Vinteren benytte Karte eller "Spindehjul", medens Karlenes Aftensarbejde var hørt op, skulde Pigerne atter malke, og til aller sidst servere "Kv'ældsnadder", hvorefter Karlene gav Køerne en Kvældsgift. Kvinderne kom ogsaa med til Markarbejdet - f. Fks. skulde de endog sprede Gødningen paa Marken. En Gaard, der var kendt som en god Plads, men med Arbejde endnu et Stykke ud over det almindelige, havde en dygtig og mundrap Pjge, som de vilde fæste igen. Hun svarede: Skal jeg blive et Aar længere, saa skulde det da være som Karl! Som Dreng sad jeg en Gang og hørte nogle gamle Koner tale om, hvorvidt de vilde ønske at gøre det hele om igen, hvis nogen kunde give dem deres Ungdom tilbage. De var rørende enige om, at det skulde de ikke have noget af. Godt, at man snart var saa vidt, at man kunde slippe for Sliddet og Slæbet! Der kom "Jyllandskarle" og Piger hertil fra nord for Kongeaaen, fordi Lønnen var større her. Mange kom fra Vestjylland og deres "Lær'" var mangelfuld, da den "Vestjydske Skoleordning" den Gang var mindre god. En Pige fra "Det blaa Vand" blev gift paa en Gaard - det blev en ferm og dygtig' Kone, der vel kendte Tallene, men ved Brøkerne sagde det Stop. Da hun var i Agerskov for at købe ind til Jul, sagde Høkeren: Skal det være et Fjerdedels eller et Ottendedels Pund Kanel? "Lad det nu blyv' ved et Fjerring, for nowe skal e'n ha, men nowe skal e'n pinde aa undvær'".

Naar man, som det sig hør og bør, fik Penge tilovers, saa var let rarest at anbringe dem ved at købe Jord, der igen kunde forøge Overskuddet, men ingen Bønder vilde sælge, det kunde mest ske ved at købe et Kaadnersted, naar et saadant blev til Salg, og saa lægge det ind under Gaarden, som Chr. Simonsen havde gjort i 1841. Naar der var flere Sønner paa en Stavn, saa var det Undtagelse, at en af de yngre købte Gaard - han havde simpelt hen ikke Penge til det, hvis han ikke kunde 
fange en Guldfugl. Hele Købesummen skulde jo udbetales, for det var ikke almindeligt med Prioriteter i Gaardene. Den honnette Ambition forbød, at man nøjedes med at købe et Kaadnersted. Saa blev man gaaende hjemme hos den ældste Broder, der havde faaet Gaarden - arbejdede med og blev regnet for at høre til Bønderne. Da Guldfeberen kom, forsagte flere af de Bøndersønner, der ikke kunde arve Gaard, deres Lykke i Kalifornien og Australien. De fleste kom efter nogle Aars Omflakken hjem igen og blev gaaende paa Stavnen. Jeg ved om flere Steder paa vor Egn, hvor der gik saadanne ugifte Bøndersønner, endog 2-3, der blev ved med at kaldes Drenge til deres Død.

Man kunde jo ogsaa anbringe Overskuddet fra Gaarden i en af de Sparekasser, der var bleven oprettet, men det var dog saa sin Sag. Saa hellere en fin 1. Prioritet. Naar en Kaptajn i Aabenraa eller paa Løjtland vilde have sig et Skib, kørte han rundt paa Landet og afhændede "Skibsparter«. Det blev kaldt at have "Skif i æ Sø".

En Bovlunder, der ellers, som ofte Tilfældet før, gik og kobslog med sig selv i Vinterens lune Stald, havde faaet Trillinger, og 'Karlene hørte ham sige: "To Skif i $æ$ Sø, 12 Stud' aa æ Staald, 2 Dreng i $\mathfrak{x}$ Vug' (Haandslag) - det klasker minsæl Else Mari!«

Det næste Slægtleds Bønder, de der var unge sidst i Fyrrerne, Halvtredserne og Tredserne, fik en ganske anden Indstilling. De vidste, at der var Velstand i Hjemmet. Bønderne blev grebet af den nationale Vækkelse, Skolelærere og Præster var af en ny Aand, enkelte Bøndersønner kom paa Rødding Højskole, og de blev Forere paa Hjemegnen. "Dannevirke" kom med Tømmervognene til Oksgaard, blev hentet der og gik paa Omgang. Min Forgængers Fader førte som ung Gaardmand Dagbog i 1850, hvor han overordentlig velskrevet skildrer sine Folelser, citerer Schiller, Oehlenschlæger og andre. Landbruget er noget, som kun hindrer Aandens Flugt. "I Morgen skal vi 
køre Rug ind, og saa kan jeg ikke komme over at se til Ingeborg. Bare det vilde give Regn!«

Det forste »Danske Samfund« i Nordslesvig blev stiftet $\mathbf{1 8 5 5}$ lios Bunde Refsiund den ældre i Bovlund. De holdt Møder, skaffede Bøger (Saxo og Snorre fra Grundtvig med egen Haand) og Sangbøger. Samme Aar holdtes et Folkemøde paa "Hyhclm«, som Pastor Vaupel og Gaardejer Lorenz Outzen i Bcvlund havde faaet i Stand. Marten Retslund gjorde Testaniente i 1859 , fordi han var syg og forudsaa, at han snart skulde lo (hvilket kom til at passe).

Den udestaaende Formue paa 4800 Rigsbankdaler skal de 2 Døtre have. Sønnen Bunde Refslund d. y. skal have Gaarden mod en forste Prioritet paa 4800 Rg.b.d. til 3 pCț. p. A. til lige Deling mellem Søstrene, og en Aftægt til Moderen. Det var altsaa en ny Anskuelse for Arvedelingen, der havde begyndt at gøre sig gældende. Døtrene skulde, saa længe de er i enlig Stand, have fri Tilflugt til Stavnen og forsørges af Stavnens Besidder med alle Fornødenheder undtagen Klæder mod en billig Erstatning.

Som Aftægtshus for Moderen skal Besidderen bygge et Hus, der er 6 Fag (18 Alen) langt og 12 Alen bredt med Jernkakkelovn og Bræddegulv tvende Steder. Han skal aarlig levere 7 Læs strøgne og 7 Læs gravede Tørv, 3 Td. Rug, 11/2 Td. Boghvedegryn, $2 \mathrm{Td}$. godt Byg, $1 \mathrm{Td}$. Bygmalt, alt frit malet, et halvt fedt Svin paa 16 Lispund (à $14 \mathrm{Pd}$.), 3 Lispund Faarekød og Bagdelen af en fed Bede, 2 Lispund Oksekød, alt roget, 1 Lispund afsmeltet Faaretalg til Lys, 1 Skæppe Salt, 2 Pd. Humle. Om Sommeren daglig 2 Kander (= 4 Liter) nymalket Mælk, om Vinteren $1^{1 / 2}$ Kande. Ugentlig 3 Pund Smør og 1/s Sues Hønserg. Om Efteraaret 4 Pd. god Faareuld, 11/2 Lispund 'uheglet Hør, 2 Td. Kartofler og 2 Læs hvidt Gulvsand. I Haandpenge betaler han 50 Rg.b.d. aarlig og Højtidsofferet. Han skal stille Vogn efter Aftægtsnyderens Ønske, holde en Pige til hende, betale Læge og Apoteker og en hæderlig og kristelig Begravelse. 
Bunde Refslund fik de 3 Ottinger Fæstegods overdraget mod 8 Rg.b.d. pr. Otting i Fæstepenge. Den 2. 2. 1870 fik han Arvefæstet ophævet mod 8 "Prøjsere» (à 3 Mark) pr. Otting.

Bunde Refslund fik de 3 Ottinger Frestegods overdraget senere blev gift, og han gav dem yderligere 3 ha Agerjord og 6 ha Eng. Han gav adskilligt bort, hvor der var Trang, og laante sine Tjenstefolk Smaabeløb, naar de skulde i Vej -- de blev alle tilbagebetalt. Da Frimenigheden vilde bygge Kirke, gav han 8000 Mark dertil. Han havde ikke alene Vilje men ogsaa Evne dertil, fordi han var blevet i dobbelt Forstand godt gift med en Gaardmandsdatter fra Bovlund, der bragte Penge og 20 ha Jord. Han var jævnt dygtig og havde Forstand paa Penge, og hans Kone var flittig og ualmindelig dygtig, da Tiderne var gode indtil sidst i Halvfemserne, var der en ikke ubetydelig Formue til Gaarden, da de døde, skønt deres Levefod var ret høj med et betydeligt Gæsteri.

Dette var en Ting for sig. Det almindelige, daglige Liv gik efter gammel Bondeskik. Som Dreng var jeg tit der Natten over, og det var saa forskelligt fra Livet hjemme, saa jeg lagde skarpt Mærke til al Ting. Selve Gaarden var firelænget - en »omlaat« straatækket Gaard. Den vestre Længe med Hestestald og en Del af Stuehuset var fornyet i 1863. Der var 2,62 $m$ til Loftet, som var gibset, saa det var Udtryk for den nyere Tids Smag og Evne. De ovrige Bygninger var ældre, en Del endog fra 1773. Vilde man ind $i$ Gaarden, gik man gennem Doren i "Gangerporten". Der var en anden "Port", men den blev kun benyttet ved Hø- og Kornhjemkørselen. „Gangerporten" gik ud til Bygaden. Om Dagen var den ofte aaben - kun om Natten blev den stænget, og saa var Gaarden som en Slags Fæstning.

Den omlukkede Gaardsplads var lun, om Sommeren lummer. Skønt Høns kaglede og Ander skræppede, syntes jeg, at det var det fredeligste, jeg vidste. Kom man der en Sønclag Eftermiddag i Hoslættiden, saa laa i Karlekammeret 2 af de faste Karle og 2 Høstkarle og sov de retfærdiges Søvn og 
snorkede, som kun Træthed og god Samvittighed kan præstere. "Stordrengen" og "Lilledrengen" svarede energisk fra Høgulvet.

Til Middag spiste hele Husstanden ved et hvidskuret Bord i » Borrestow«. Hver Ugedag havde sin Ret. 2 Dage om Ugen gav det Pandekager, Budding, Ovnkage eller Melboller, foruden Skemaden, der altid spistes efter Gaffelmaden fra 3 Fællesfade. Der brugtes Træskeer, enkelte havde sine Ejendomshornskeer. De 5 Dage om Ugen gav det saltet og røget Sulemad. Kun nogle Uger efter Slagtedagen gav det fersk Kød, Blodpølser, "Fersksup'« og „Sortsup'«. De kogte Kartofler blev med Pillen paa hældt i Dynger ned over Bordskiven, og saa kunde enhver pille sig en saa stor Stak Kartofler, som han troede, han kunde spise. Saa kom Pigerne og ragede med en Karklud Pilningen ned i Svinespanden, fordelte Træbrikser til enhver, og Madmoderen stod for Bordenden og skar et Stykke Okse- eller Faarekød og et Stykke Flæsk af til hver. For den anden Ende sad Gaardmanden, Karlene i Rangfølge, nederst Stordrengen og Lilledrengen. Pigerne skulde spise staaende. Naar Sulet var tildelt (der blev ikke budt anden Gang), koml Pigerne og satte 2 Pander med Duelse paa Bordet, hvori man dyppede Kartoflerne. Søndag og Mandag fik man Grønkaalssuppe eller gule Frter. Man fik tit Vælling og Grød, sjælden Sødsuppe. Til Aftensmad fik man nykogt Grød med skummet Mælk til uden Brød, eller kogt Mælk med Grød i og et Stykke Fedtebrod til. Til Davre fik man kogt Mælk og Grød og et Stykke Fedtebrød. Om Vinteren fik man wKvældsnar'« kogt Mælk og et Stykke Fedtebrød. Om Sommeren Formiddags- og Eftermiddagsmellemmad: 1 Stykke Rugbrød med Pølsepaalæg og 1 Stykke med hjemmelavet Skummetmælksost.

For meget af Arbejdet var der fra gammel Tid Hævd. En Karl skulde i en Dag stryge 2000 Tørv og slaa 1 Karlsslæt $=1$ Td. Land $=2 / 3$ ha Græs. Man vidste, at hver Eng var saa og saa mange Karlsslæt, og hvert Spænd skulde køre et bestemt Antal Læs Hø fra hver Eng. Tørvestrygningen og Græsslaa- 
ningen var vel svært Arbejde, men naar man hang i, kunde Waalet naas i 8 Timer, for Resten kunde man sove eller hvile. Naar der blev stakket $\mathrm{Hø}$, kunde der først begyndes, naar Duggen var borte, men til Gengæld blev man ved, til man var færdig, eller til det blev morkt $i$ den lange Sommeriag. Strengest var Hjemkørselen. Vognene blev efterhaanden storre, og dermed tog det fastsatte Antal Læs længere Tid. Der blev begyndt Kl. 2 om Natten, kun holdt Hvil, mens man spiste, og ofte blev Kl. 10 om Aftenen, før Dagens sidste Las kom i Hus. Karlene hvilede jo, mens de kørte, og Hestene, mens der blev læsset paa og læsset af. Det kneb værst mel Søvnmangelen. Man fortalte, at da Manden paa en Gaard en Morgen under Hosthjemkørselen kom op Kl. 2, sad Karlene og sov med Skeen i Haanden ved Bordet, hvor de havde sat sig til Nadveren. Hos Norbroders fik Karlene en Gang »Høfeber", da de havde kørt Hø i 3 Dage. Høslætten var Aarets travleste - og muntreste Tid. En Gaard havde i et særligt frugtbart Aar 300 Læs Hø. Skønt Læssene var mindre end nu, er det dog en stor Arbejdsindsats, da der ikke kendtes til Maskiner. Der var 40 ha at gaa over med Le og Haandrive. De storre Gaarde havde hver 2 ekstra "Høstkarle« i Juli Maaned. Det var Husmænd fra Nørrejylland, der kom Aar efter Aar, indtil de blev for gamle, for at tjene den store Maanedsløn (i Firserne 1 "Prøjser" $=3$ Mark om Dagen). Kornhøsten var ikke nær saa svær, saa den kunde man sagtens klare med eget Tyende. Roer var endnu ikke i Brug. Da man var blevet færdig med Merglingen, havde man en "rele« Vinter. Man blev gerne færdig med Vinterpløjningen til November, og saa var cler ikke andet at lave end at rugte Kvæget og bruge Plejlen, indtil man havde udtærsket.

Skønt man ikke havde Besvær med Roer, tog Røgtningen adskillig Tid. Da der ingen Fodergang var, skulde man bagfra op mellem hvert ${ }_{\text {Par }}$ Kreaturer med hver Givt. Der var ikke nogen egentlig Krybbe, kun en smal Fjæl paa Kant for at holde lidt paa Høet, Skaftekornet og Halmen. Hvert Par Kreaturer skulde 2 Gange om Dagen løsnes, "slaas af til Vands", 
for at de kunde gaa hen til Vandtruget. De havde ogsaa godt af at røre Lemmerne, hvad særlig Ungkvæget forstod at paaskønne, saa det gav Besvær og der blev uddelt mange Klø, for de igen kom paa Plads og blev bundet. En noget heftig Bonde svovlede over dem, medens de lavede Spilopper. Karlene morede sig med at optælle, at der gik gennemsnitlig 20 Stokkeslag cg 25 Eder paa hvert Par, der havde været tilvands.

At tærske Korn med Plejl ansaas for et haardt Arbejde, særlig naturligvis naar det var paa Akkord, hvorfor man siger: "Han æder som en Tøndetærsker«. Det var ikke et Arbejde, der kunde skulkes ved. Naar Plejlen var i Gang, lød de taktfaste Slag over hele Gaarden - det gav en vis Idyl og Hygge. Jeg har tærsket med Plejl i flere Vintre, og husker det som skrækkelig kedeligt med det ensformige Arbejde Dag for Dag --. De gamle syntes, at det var saa rart og "rele" at kunne gaa i Hi hele Vinteren i Stald og Lo og kunne være ligeglad med, om Vejene udenfor fog til. Man skulde jo kun til Mølle en Gang hver fire Uger og til Kirke efter Skik og Brug. Det samme kunde forresten vare vanskeligt nok, for Hestene var den sjældne Gang, de kom url, saa kaade, saa de ikke var til at styre, med mindre man havde redet dem træt først, og saa kunde det endda gaa galt. Der gaar endnu Frasagn om, hvorledes et Køretøj kørte løbsk fra Kirken, og alle Passagererne fik Brud paa Lemmerne ved at vælte paa den frosne Jord.

Der herskede patriarkalske Forhold. Til daglig spiste hele Husstanden af samme Gryde, gik alle klædt i hjemrnelavet Tøj, og Tyendet blev ofte i aarevis i samme Gaard. Jeg ved endog om flere TilfæIde, hvor Tyendet blev hele Livet i samme Gaard og blev »flegfør" efter jydske Lov. Pe'r begyndte som "Lilledreng" i en Gaard, avancerede til "Stordreng", "Tredjekarl", "Andenkarl«, "Avlskarl«, som blev alt betroet, da han blev gammel, gik han og lavede Puslearbejle, og nu blev han regnet for at høre til Familien; han syntes selv, at han havde Part i Børnene, som han tit havde passet. Han kom med ind, naar der kom fremmede. Da han blev svag, blev han omhyggelig 
plejet, og da han døde, blev der holdt en Begravelse, som for en af Familiens egne - sat en Sten paa hans Grav, og den "flegføres « sammensparede Skillinger gik, som jydske Lov bestemmer, tilbage til Stavnen.

Saa man nærmere til, var den sociale Forskel ikke saa lille, som den kunde synes. Det hørte til en meget sjælden Undtagelse, at en Gaardmandssøn giftede sig med en Tjenestepige, eller en Gaardmandsdatter med en Tjenestekarl. Der var vel ikke stor Forskel paa Bønderbørns og Tyendets Levemaade, naar de i Fællesskab arbejdede paa Gaarden. Naar en Tjenestekarl og en Pige vilde giftes, ydede Husbonden dem ofte en vis Hjælp, men det Liv, de saa gik ind til, som Arbejdsfolk, Landsbyhaandværker, Husmænd o. s. v. var fattigt. Der var Brug for "Mergelkrittere", og det var et haardt Arbejde at trille Mergel op af Graven. Det og at være Tøndetærsker om Vinteren blev kun daarligt betalt. Det samme gjaldt for Husmænd og Haandværkere, selv om det var noget bedre. Mange af dem trøstede sig med den billige Brændevin. Fausbøl fortæller om Arbejdsfolk, der spiste selvdøde Kreaturer, og endnu i 1880erne har jeg set det.

Skønt de altsaa havde det meget smaat i Forhold til Bønclerne, var de dog ikke personligt fortrykte. Ogsaa de var fribaarne. Adskillige havde en Ko og arbejdede sig trods de ringe Kaar fremad, saa Slægten fik et Kaadnersted, og i et enkelt Tilfælde endte den med at have 2 Gaarde. En Skrædder fra en Naboby, der kom i Hjemmene og syede det Vadmel, man havde lavet, var godt hjemme i Holberg. En Arbejdsmand, der med primitive Apparater kunde lave et Slags Nivellement, blev benyttet til at planere Vandingseng. Han læste meget. En Dag kom han ind til B. Refslunds med en "Letter", skraalende paa en ny Sang, der var kommet til Egnen, hvori der forekommer den passende Strofe: "Jeg har det herligste Rejsefølge». De, der var drikfældige, kom naturligvis ikke fremad, og deres Kone og Familie havde det ondt. En gik som Kagekone, andre tjente paa anden Maade noget for at faa Føden til Fanilien. 
"Hans» var lige umaadeholden med Drik og Arbejde. En Aften kom han og Kristian Slagter ind til Fader for at laane et Køretøj; de sagde, at de havde faaet Lov til at tage et Stykke Hornkvæg, som var død af "Rasselbrod" (Miltbrand). Husslagteren vilde sælge Huden (hvilket var forbudt og sundhedsfarligt), og "Hans« vilde benytte Kødet. Da de begge var fulde, og Fader fraraadede dem at benytte Dyret, vilde han ikke laane dem Køretøjet. De gik saa i Gang med Arbejdet og benyttede Trillebør. Hans' Kone malkede nogle Uger hos os: En Morgen $i$ et forrygende Snevejr spurgte jeg hende om, hvorledes hun havde kunnet komme. "Ja, Hans soj aa, da æe stoj op, hvad Satan vil Do ha aa æ Bælle i Daw«. Ogsaa med Eder var Hans umaadeholden - ellers var han god nok. Han blev gammel og kroget, før han døde.

Hans Hünding i Bovlund var gift med en Søster til den som tysk Landdagsmand kendte Amtsdommer Jürgensen. Jürgensens havde Dansk som Modersmaal, men fra gammel Tid var de paavirkede af tysk Kultur, og de blev slesvigholstensk sindede. Før 1864 lagde man ikke Mærke til, at Hans Hündings Sindelag var anderledes end de andres. Men da de andre blev fortvivlede over Tilbagetoget fra Dannevirke, tog han det let.

I 1866 byggede han et nyt Stuehus, der blev typisk for, hvad man ønskede og troede at have Raad til: $25 \mathrm{~m}$ langt, 10,5 bredt, 3,15 m Loftshøjde. Skifertag, 2 Kviste med Takker paa Kviste og Gavle. "Han skrev op, hvad det kostede, men da han kom til 6000 "Prøjsere" (18,000 Rigsmark), blev han led ved det.\& Hünding hejste i 1870-71 det slesvigholstenske Flag, naar der kom tyske Sejre, og da Byens Karle i den Anledning troppede op paa Vejen uden for Gaarden, gik' han i Stalden med en ladet Jagtbøsse. Han fik saa en preussisk Gendarm til at bo hos sig. Almindelige Lovovertrædelser var der ikke, men han gik saa paa Jagt efter, »de Syttenaars«, der var udvandret for at undgaa Soldatereden. De kom jo i Smug hjem paa Besøg. Branderup Møllerkone sagde til ham, at det maatte da være sært 
saadan at gaa paa Menneskejagt, men Gendarmen svarede: "Det er nu min Gesjæft, lille Madam!"

I 1875 solgte Hans Hünding Gaarden til 3 Naboer, og købte en enligtliggende Gaard i Vellerup. Grunden var dels en national: Naboerne vilde gerne have den tysksindede ud af Byen, og han vilde gerne fra det nære Naboskab med de stærkt dansksindede. Men desuden var det endnu Tidens Løsen, at det g.jaldt om at købe al den Jord, man kunde faa fat paa. Naboerne delte Jorden mellem sig. Den ene, Bunde Refslund d. æ., fik desuden Bygningerne, som han benyttede i Stedet for sine egne, der var ældre. Det var en »omlaat«, firlænget Gaard, der blev nedbrudt med Undtagelse af en Del af Stuehuset og en Stump Stald, der blev Bygninger for et Husmandssted.

Foruden Hans Hünding var der en tysksindet Gaardejer, som var tilflyttet fra den Gottorpske Del, og hans "Nisse var flyttet med, og saa var der 3 Kaadnere, hvis nationale Sindelag var enduu mere mærkværdig. De kunrle ikke et tysk Ord; havde ikke Spor af tysk Kultur - hvad der var i dem af gammel Kulturarv, var dansk. Men de sagde: E er tysk, og bar med rank Ryg alle Drillerier, de i den Anledning var udsat for. Grunden var ene og alene "Tras«, Modsigelseslyst. Havde Flertallet været tysksindede, skulde de nok have vedkendt sig detes Danskhed, for den var, trods deres egen Benagtelse, ægte nok. En Del af deres Efterkommere har da ogsaa senere erkendt deres sande Natur. Alle tysksindede var i 1864 Slesvigholstenere, men blev efterhaanden Prøjsere, selv om de vel nok lavde det som en flink Haandværker, der fra den Gottorpske Del var indvandret til vor Naboby. Han sagde for et Valg: "Egentle vil' $x$ helst haj en lilìe Herzog, men det maa $æ$ jo it!" I mange Aar undlod Bovlunds faa Tysksindede at gaa til Valg, s.aa vort Valgdistrikt kun havde danske Stemmer, hvilket udsatte vor dansksindede Larer for Forfølgelse i Form af tyske Kursus og tilsidst Tvangsforflyttelse til en frisisk Egn. Med Lndtagelse af det meningslose $i$, at Mennesker af danck lRod og med dansk Modersmaal kaldte sig tỵske, saa var vore Hjem- 
metyskere agtværdige Folk. De led heller ingen Ulemper for deres Sindelag, undtagen naar de en sjælden Gang optraadte udæskende.

Bønderne drev et vidtstrakt Gæsteri, og de var meget gæstfri. Man kørte milevidt (4-6 Mil afskrækkede ikke) for at besøge Slægtninge og Bekendte. Da Cornelius Appel 11864 blev fordrevet fra Tønder, boede han med hele Familien i 6 Uger hos en Gaardejer i Bovlund, skønt de ikke var i Slægt, men de var folkeligt og kirkeligt ligesindede. Man kørte til Visby og Københoved - ogsaa paa Grund af aandelig Overensstemmelse, saa der blev drøftet Vej og Maal for den gode Sags Fremme. Som lille Purk har jeg siddet og set paa Hans Andersen Krüger et af de sidste Aar, han var rask, naar han ivrig snakkede, saa Spytstænk fløj, om "Sagen«, "Retten " og sHaabet«, alt imens han som i andre Tanker hældte Rom i Grogglasset. Naar Morbroders skulde have "Gæst«, blev jeg tit med Nordbaggen "Kasper" sendt til Høkeren efter en Eidammerost, 1 Flaske Akvavit og 1 do. gammel Jamaikarom. Fønst fik man Eftermiddagskaffe, foruden Blødbrødet talte jeg, at der en Gang var 23 forskellige Slags Smaakager -. 'Til Aftensmad gav det ofte 2 Slags Steg, om Aftenen fik man Grog (Toddy), og til Slut Aftenskaffe med Kager. Man spillede ti Pennings Whist, ofte blev Kortene lagí, naar det mere vigtige blev debatteret. Skønt alle var Bønder, blev Landbruget sjælden berørt. Man nød aldrig Spiritus til Overmaal - kun ved Bryllupper kunde det ske, at nogen fik en Taar over Tørsten. Festligst var det næsten hos Laust Arnums. Hans ugifte Onkel Jacob Arnum havde i den gamle Gaard under Bakken samlet en Formue, da han tog Nevøen til sig. Skønt Jacob Arnum nødig saa det, byggede Laust Arnum en ny flot Gaard oppe paa Bakken. Buet Glas i Ruderne, "Malerier", malet paa Væggene. Laust Arnum mageskiftede og købte Jord, saa han ialt fik 138 ha. Han købte de bedste Dyr, han kunde faa. Han drev Hingsteopdræt - da han havde flest, havde han 14 Hingste. Det var et stolt Syn at se de vælige Dyr blive "mønstret«, saa. 
Skoene slog Gnister mod Stenbroen. Naar Laust Arnum tog mod Gæster, aabnede han Døren og slog kongeligt ud med Haanden: Værsgod!, og man vidste, der intet blev sparet, for at man kunde faa det godt og morsomt

De, der havde økonomisk Sans, gjorde ogsaa en Del af Tidens Opgangstegn med, men de fik de gode Indtægter til godt og vel at dække Udgifter.

Alle havde Fornemmelsen af, at de var født ind i Velstand, de indsaa, at den forpligter, og de, der manglede okonomisk Sans, sørgede ikke for en fornuftig Balance. Nogles "Grundbøger" viser, at de Tid efter anden selv i de opadgaaende, gode Aar fik en ny Hypotek indfort. De kunde faa Laan f. Eks. fra Roost, hvor der samledes store Formuer. Nu kan man let være bagklog og undre sig over, at de ikke i Tide kunde se. hvor det bar hen. Men de kunde ikke tage Skeen i den anden Haand. De levede ordentligt, men de var ikke opdraget til at have Forstand paa Penge, og deres Landbrug gav for lidt. Da Konjunkturomslaget kom sidst i Halvfemserne, korte de fast. Man saa det ikke alene i Bovlund, men rundt omkring var der saadanne enkelte, som. kørte fast. Græmsen for Belaaningsmulighederne var saa lav, at naar de solgte nogen Jord og Besætning, lejede andre Arealer ud til Hoslet og Græsning, saa kunde de beholde en lille Gaard tilbage fri for Ydelser. Paa den maatte Levefoden jo sættes ned. En enkelt holdt det gaaende ved, at han havde det Held at arve flere Penge, endog store Beløb, saa han først hen mod Aarhundredskiftet maatte sælge sin Gaard - han kunde give enhver sit.

Lærer L. B. Poulsen fra Roddingegnen var blevet gift med en Pige fra Bovlund, blev Lærer i Rangstrup, men rejste paa Grund af det preussiske Militærvæsen til Fyn som Forstander for Vejstrup Højskole i 2 Aar. Da han vandt en Sag ved de preussiske Domstole, hvorved han blev anerkendt som tysk Indersaat, kabte han et Husmandssted paa Bovlund Bjerg, livor han i 1870 byggede et nyt Stuehus med en Sal til folkelige og kirkelige Møder. Der holdt grundtvigske Præster fra 
Kongeriget Gudstjenester og folkelige Møder, indtil de blev truet med Udvisning. Saa kom Cornelius Appel fra Rødding. 1879 blev Poulsen præsteviet, og der dannedes en Frimenighed med 2 Kredse paa Vestkysten. Kun 3 Gaardejere, 1 Kaadner, 2 Far Aftægtsfolk og 1 Købmand i Bovlund var Medlemmer - der var Medlemmer fra de omkringliggende Byer. Forholdet til dem, der ikke var Medlemmer af Frimenigheden, var godt mange kom til de folkelige Møder i Salen. Dette Forhold holdt sig i en Aarrække, men saa i 1890erne kom der ny Tilgang af Gaardejere, Husmænd, Haandværkere og Arbejdsfolk, saa det ikke kun var en Gaardejerklike. Frimenigheden blev dog aldrig ret stor.

I 1896 byggede den en Kirke paa Bovlund Bjerg. Da Frimenigheden vilde tage den i Brug, lukkede de tyske Myndigheder den. Frimenigheden førte Sag for at faa Lov til at benytte sin egen Kirke. Den tabte ved alle Unclerinstanser, indtil Sagen i 1900 blev vundet ved Kammerretten i Berlin.

I Bovlund var der af

\begin{tabular}{|c|c|c|c|}
\hline & Gaarde & $\left|\begin{array}{c}\text { Husmands- } \\
\text { steder }\end{array}\right|$ & Huse \\
\hline i 1815 & 16 & 12 & 8 \\
\hline i 1880 & 11 & 11 & $\begin{array}{l}\text { 21, deri } 1 \text { Skomager, } 1 \text { Smed, } 1 \\
\text { Byggehaandværker, } 1 \text { Købmand og } \\
1 \text { Skole. }\end{array}$ \\
\hline i 1920 & 15 & 13 & $\begin{array}{l}\text { 16, deri } 2 \text { Byggehaandværkere, } 1 \\
\text { Smed, } 2 \text { Købmænd, } 1 \text { Skole }\end{array}$ \\
\hline i 1941 & 16 & $\begin{array}{l}\quad 22 \\
\text { deraf } 11 \\
\text { Statsbrug }\end{array}$ & $\begin{array}{l}\text { 18, deri } 1 \text { Smed, } 1 \text { Byggehaand- } \\
\text { værker, } 3 \text { Kobmænd, } 1 \text { Præste- } \\
\text { bolig og } 1 \text { Skole. }\end{array}$ \\
\hline
\end{tabular}

Under Fremmedherredømmet 1864 til 1918 aftog Befolkningen i Sønderjylland, især paa Landet og særlig under Udvandringen indtil 1890. Samtidig var Græsningsdrift lønsom, Klima og Jordbund egnede sig til det, og de tyske Lovbestemmelser hindrede ikke Nedlæggelse af Landbrug. I vor Nabolands- 
hy var der kun 1 Gaard tilbage - Resten laa til vedvarende Græs. I et Par af de nedlagte Gaardes Stuehuse boede Arbejdsfolk, der passede Hegnene og tilsaa Kvæget. Ejerne og Græsserne boede langt borte. $\mathrm{Nu}$ er der kommet 27 Statsbrug, deraf flere Smaagaarde.

I Bovlund blev der, medens Landbefolkningen aftog, nedlagt 2 Gaarde ved Arvedeling, saa Jorden kom til andre Gaarde i Byen. Over hele Nordslesvig florerede Gaardslagtning; Ejendomshandlere havde derved et indbringende, men landsskadeligt Erhverv. Jorden blev solgt til den højestbydende, ligegyldigt hvordan den laa i Forhold til den nye Ejers Bygninger. 3 Gaarde i Bovlund blev solgt til Gaardslagtere. 2 af dem blev derved nedlagt, 1 blev formindsket. I Perioden blev de store Gaarde for'størret.

Efter Genforeningen er 2 af de største Gaarde omtrent blevet halveret, og paa deres Jord er kommet 11 Statshusmandsbrug, der klarer sig godt.

Den Tid, da Besiddelsen af Eng var en Rigdomskilde for Landbruget, er forlængst forbi, og derfor hedder det ikke mere som for: "Bovlund, Bovlund er en Blom', aller a den kom «. Nu er det ikke som i Firserne, at der i Høbjergningstiden kommer store Skarer af "Idlejere" fra Østersognet for at hente Hø. Kunstgødningen har medført, at de nu ikke har rlet behov. Vandrer man tilbage for at se over en Landsbys Liv, er man udsat for vell Bedommelse af Fremskridtene at falde i en af Grøfterne ved Vejen. Man kan havne $i$ den ene ved at sige, som der staar i Sangen: "Den Gang jeg var Pige, da var der Piger til«. Men man kan ogsaa havne $i$ den ved den anden Side ved at tro, at det er givet, at ethvert Fremskridt foruden at give materiel Fordel og Bekvemmelighed, ogsaa skulde bringe en aandelig Berigelse i Livsførelsen og Livsføleisen.

Før de store Fremskridt i Trafikmidlerne kørte Amtmanden med Hestekøretøj fra Haderslev de 5 Mil ud i Vesteramtet, hvor han overnattede hos $H$., der ejede en stor Gaard og var klog, dygtig, oplyst og selvstandigt tænkende. Under Besøget 
bad Amtmanden om at blive vist Vej til et "vist Sted«. $\mathbf{H}$. maatte indrømme, at de ikke ejede et saadant, men henviste ham til at benytte Læplantningen eller Stalden. Amtmanden svarede, at det kunde han ikke. H. fandt paa Raad: Kudsken og en Karl holdt en Stige vandret i passende Højde i Stalden, og saaledes blev Amtmanden hjulpen. Hvilket umaadeligt hygiejnisk og æstetisk Fremskridt til vore W. C.! Men personligt vilde $H$. ikke have været større eller lykkeligere, hvis han havde haft W. C. - ja han var endog gaaet Glip af den Moro over de tossede Stajsfolk, som ikke forstod at hjælpe sig selv. Oehlenschlägers Skrifter var vel heller ikke blevet endnu mere poetiske, fordi han havde haft W. C.! Vore Maskiner og Elektriciteten - ja, hvilken Lettelse og Bekvemmelighed! men personligt, aandeligt Udbytte bringer de kun, saa længe man undrer sig over Foreteelsen. Naar vi forst anser det for selvfolgeligt, at Tørvene, Fortidens opmagasinerede Solvarme, brænder i Aabenraa, og vi i Bovlund tapper det ud som Lys og Kraft, saa har det kun materiel Værdi for os.

Selv om man ikke er Historiker, gør man vist bedst $i$ at forsøge paa at sætte sig ind i den Tids Forudsætninger, naar man vil skønne rigtig over en vis Tid' og Sted. Vore Børnebørn vil formodentlig undre sig over, at vi kunde undvære og ikke savne Indretninger, som de nyder godt af.

M. Refslund Poulsen. 